\title{
Evaluasi dampak perikanan tangkap terhadap sumber daya ikan dan lingkungan di Teluk Amurang Kabupaten Minahasa Selatan
}

\author{
Evaluation of fishing gears impact on fisheries resources and their habitat in Amurang Bay, \\ South Minahasa Regency
}

WATY CH. MAMOTO*, IVOR L. LABARO dan EMIL REPPIE

Program Studi Pemanfaatan Sumberdaya Perikanan, Fakultas Perikanan dan Ilmu Kelautan, Universitas Sam Ratulangi, Manado 95115

\begin{abstract}
Traditional fishing activities in the coastal areas of Amurang Bay are often regarded as one of the factors that cause changes in aquatic ecosystems. Therefore, it is necessary to evaluate the fishing process of any fishing gear used by local fishermen. This study aimed to evaluate the impact of fishing gear on marine resources and their habitats. The research was conducted using survey method through direct observations on fishing process to know the physical benthic damage caused by fishing gear, the by-catch or discard-catch, and the composition of the catch. Fishing gears used by fishermen in Amurang Bay consist of bottom hand line, vertical hand line, encircling gill net, beach seine, barrier trap, casting net, portable trap and fish spear. Results show that almost all fishing gears used (75\%) could give impact to fisheries resources and their habitat. There is a need to select, modify and develop the fishing gear and its operation techniques to a more responsible manner.
\end{abstract}

Key words: fishing gear, fishing gear impacts, fish resources and environment

\begin{abstract}
ABSTRAK
Kegiatan perikanan tradisional di wilayah pesisir Teluk Amurang sering dianggap sebagai salah satu faktor yang mengakibatkan perubahan ekosistem perairan. Oleh karena itu, perlu mengevaluasi proses penangkapan ikan dari setiap alat tangkap yang digunakan oleh nelayan lokal. Sehingga tujuan penelitian ialah mengevaluasi dampak alat tangkap terhadap sumber daya perikanan dan habitatnya. Penelitian ini dilakukan melalui metode survei dengan pengamatan langsung terhadap proses penangkapan ikan; untuk mengetahui kerusakan fisik bentik akibat alat tangkap, adanya by-catch atau discard dan keragaman komposisi ikan hasil tangkapan. Alat tangkap yang digunakan oleh nelayan di perairan Teluk Amurang terdiri dari 8 jenis, yaitu pancing dasar, pancing noru, soma paka, pukat pantai, sero tancap, jala lempar, bubu dan panah ikan; sedangkan jenis ikan yang umum tertangkap terdiri dari 15 jenis. Hampir semua jenis alat tangkap (75\%) berpeluang memberikan dampak terhadap sumber daya ikan dan habitat lingkungan perairan di Teluk Amurang. Perlu menyeleksi, memodifikasi dan mengembangkan alat tangkap dan teknik pengoperasiannya ke arah yang lebih bertanggung jawab.
\end{abstract}

Kata-kata kunci: alat tangkap, dampak alat tangkap, sumber daya ikan dan lingkungan

\section{PENDAHULUAN}

Pembangunan kawasan pesisir dan pulau-pulau kecil selama ini bertumpu pada kegiatan perikanan, pertambangan, pariwisata, perhubungan dan jasa kelautan lainnya. Kegiatan perikanan lebih

\footnotetext{
* Penulis untuk penyuratan; email: chatarina.mamoto@yahoo.com
}

dominan, tetapi sayangnya produktivitas perikanannya rendah karena adanya penangkapan ikan yang berlebihan, baik secara biologi maupun secara ekonomi dan sosial, serta kerusakan lingkungan (Dahuri, 2000).

Masalah kerusakan lingkungan bukan hanya diakibatkan oleh peningkatan jumlah penduduk, tetapi juga dari kenyataan bahwa pengeksploitasian sumber daya alam yang ketersediaannya 